\title{
Youth Knowledge about Reproductive Health during the COVID-19 Pandemic
}

\author{
Sella Ridha Agfiany ${ }^{1}$, Eka Riana ${ }^{2}$, Nadiah ${ }^{3}$, Nadya Rahmawati ${ }^{4}$ \\ ${ }^{1,2,3,4}$ Department of Politeknik 'Aisyiyah Pontianak, Politeknik 'Aisyiyah Pontianak College, Pontianak, \\ Indonesia \\ Corresponding Author: Sella Ridha Agfiany
}

DOI: https://doi.org/10.52403/ijshr.20220126

\begin{abstract}
Background: Covid-19 cases are still increasing. Global data based on WHO records dated May 16, 2020, world covid cases reached four million. The highest number of Covid 19 is in America followed by Europe. The death rate caused by this case worldwide reaches more than 300 thousand. The COVID-19 pandemic has an impact on most community activities, including groups called families and children. Changes in daily activities for children and adolescents do not only have an impact on their physical aspects, but also on mental health aspects because these changes occur quite quickly.
\end{abstract}

Methods: The type of research used is quantitative research methods with descriptive research design. The quantitative research design used was an analytic survey method with a cross sectional approach. Purposive sampling technique with a total of 65 respondents. Quantitative data analysis using chi-square.

The results of the analysis show that the level of knowledge is good (53.8\%), the effect of the respondent's health is good (43.07\%).

The conclusion is that female students know the impact of the COVID-19 pandemic on reproductive health well. Respondents still need more information to be obtained about reproductive health in adolescents during the Covid 19 pandemic. Strategies to increase information about adolescent reproductive health during the Covid 19 pandemic must be improved to deepen adolescent knowledge in understanding reproductive health.

Suggestion: Strategies to increase information about adolescent health during the Covid 19 pandemic must be improved to deepen adolescent knowledge in understanding health.

Keywords: Teen, Covid 19, Reproductive Health.

\section{INTRODUCTION}

Since adolescence, a child can see changes in body shape accompanied by changes in structure and function. The maturation of the pituitary gland affects the body's growth process so that adolescents get the characteristics as adult men and as adult women. Adolescence begins with puberty, which is a period of physical changes (including physical appearance such as body shape and body proportions) and physiological functions (maturation of sexual organs). These bodily changes are accompanied by the gradual development of primary and secondary sexual characteristics.

Covid-19 cases are still increasing. Global data based on WHO records dated May 16, 2020, the world's Covid cases reached four million. The highest number of COVID-19 is in America, followed by Europe. The death rate caused by this case worldwide reaches more than 300 thousand (WHO, n.d.). Positive cases of covid in Indonesia have jumped rapidly since March recorded in the hundreds

Teenagers begin to be curious about human sexual life. For this reason, they seek information about sex, either through books, movies, or other pictures that are done 
secretly. This is done by teenagers because of the lack of dialogue that is communication between adolescents and adults, both parents and teachers regarding sexual issues, where most people still consider it taboo to talk about sexual issues in everyday life. Adolescence is a period in which an individual experiences a transition from childhood to adulthood accompanied by radical physical, psychological and behavioral changes, so that adolescents begin to wonder about various phenomena that occur in the surrounding environment as the basis for the formation of their selfworth. . Since adolescence, a child can see changes in body shape accompanied by changes in structure and function. The maturation of the pituitary gland affects the body's growth process so that adolescents get the characteristics as adult men and as adult women. Adolescence begins with puberty, which is a period of physical changes (including physical appearance such as body shape and body proportions) and physiological functions (maturation of sexual organs). These bodily changes are accompanied by the gradual development of primary and secondary sexual characteristics.

\section{LITERATURE REVIEW}

Adolescence is a period in which an individual experiences a transition from childhood to adulthood accompanied by radical physical, psychological and behavioral changes, so that adolescents begin to wonder about various phenomena that occur in the surrounding environment as the basis for the formation of their selfworth ${ }^{1}$.

Coronaviruses are a large family of viruses that cause illness ranging from mild to severe symptoms. There are at least two types of coronavirus that are known to cause disease that can cause severe symptoms such as Middle East Respiratory Syndrome (MERS) and Severe Acute Respiratory Syndrome (SARS). Coronavirus Disease 2019 (COVID-19) is a new type of disease that has never been previously identified in humans. The virus that causes COVID-19 is called SarsCoV-2. Corona virus is zoonotic (transmitted between animals and humans). Research says that SARS was transmitted from civet cats to humans and MERS from camels to humans. Meanwhile, the animal that is the source of COVID-19 transmission is still unknown.

The Covid-19 pandemic has caused impacts such as a reduction in public visits to health facilities, an increased risk of unwanted pregnancy (KTD), gender-based violence. And in this aspect, teenagers get a bigger impact than other groups, especially gender-based violence including child marriage that is now happening. Adolescent development is the development of adolescents who reach new, more mature relationship patterns with peers of different sexes in accordance with ethical and moral beliefs of decency prevailing in society. Adolescence is a transitional period from childhood and lasts usually between the ages of 12-21 years for women and 13-22 years for men ${ }^{2,4}$. Reproductive health according to the Ministry of Health of the Republic of Indonesia is a state of health, comprehensively including physical, mental and social position related to reproductive organs, functions and processes, and the idea that reproductive health is not only a condition free from disease, but also how a person can have safe sex and satisfying before and already married.

According to Leavel and Clark, promotive and preventive efforts are health education. Health education is an application of the concept of education in the health sector in the form of an activity to help individuals, groups or communities in improving their abilities or behavior, to achieve health in environmental factors. There are four levels of disease prevention from a public health perspective, namely health promotion, specific protection, early diagnosis, and disability limitation. Besides that, teenagers can also strengthen their faith, fill their free time with positive activities and be selective in choosing friends. 
Adolescents begin to clearly feel an increase in their sex drive, for example, there is an interest in other people and a desire for sexual satisfaction. Maturity of reproductive organs and psychological development of adolescents who begin to like the opposite sex as well as the flow of information media, both electronic and nonelectronic, will greatly affect the sexual behavior of the individual teenager (Mappiare, 2012) procreation, meaning that they can have offspring. However, this does not mean that adolescents are physically able to reproduce safely. Healthy reproductive age for women is between 20 30 years. There are various factors that influence it. For example, before a woman is 20 years old, her reproductive organs, such as the uterus, are not physically ready to maintain the results of fertilization and fetal development. In addition, mentally at this age women are not mature and mature enough. Young mothers usually have poor prenatal care skills due to low knowledge and shyness about coming to the health care center for a check-up.

\section{MATERIALS \& METHODS}

The type of research used is a quantitative research method with a descriptive research design. The quantitative research design used is an analytical survey method with a Cross Sectional approach. The independent variable in this study was the COVID-19 pandemic, while the dependent variable in this study was the level of knowledge. Researchers collected respondent data during the COVID-19 pandemic by providing questionnaires that were distributed via a google form link at the Polytechnic 'Aiysiyah Pontianak. Respondents who met the inclusion and exclusion criteria of the study were given an explanation regarding the course of the research, the research objectives, the benefits of the research, and the respondent's right to withdraw if they did not wish to conduct the research.

\begin{tabular}{|c|c|c|c|c|}
\multicolumn{7}{|c}{ Statistical Analysis } \\
\begin{tabular}{|c|c|c|c|} 
Healthcare \\
Knowledge
\end{tabular} & $\begin{array}{c}\text { Not } \\
\text { Enough }\end{array}$ & Enough & Good & Total \\
\hline $\begin{array}{c}\text { Effect of } \\
\text { Covid 19 }\end{array}$ & $\mathrm{F}(\%)$ & $\mathrm{F}(\%)$ & $\mathrm{F}(\%)$ & $\mathrm{F}(\%)$ \\
\hline Not Enough & 2 & 1 & 2 & 5 \\
& 3,08 & 1,54 & 3,08 & 7,69 \\
\hline Enough & 3 & 7 & 18 & 28 \\
& 4,64 & 10,77 & 27,69 & 43,08 \\
\hline Good & 3 & 17 & 12 & 32 \\
& 4,62 & 26,15 & 18,46 & 49,23 \\
\hline Total & $\mathbf{8}$ & $\mathbf{2 5}$ & $\mathbf{3 2}$ & $\mathbf{6 5}$ \\
& $\mathbf{1 2 , 3 1}$ & $\mathbf{3 8 , 4 6}$ & $\mathbf{4 9 , 2 3}$ & $\mathbf{1 0 0}$ \\
\hline
\end{tabular}

\section{RESULT}

Knowledge is information obtained about objects that are received through sensory receptors and processed in the central nervous system. Knowledge is influenced by educational factors, sources of information, socio-cultural, economic, environmental, experience, and age ${ }^{3}$. The subjects in this study were teenagers with an age range of 17-20. Cognitive development in adolescents is very fast, but each teenager learns and receives information in a different way. So it is important to know the most appropriate way of learning per individual to get maximum knowledge of what is required. The strategy that can be given to increase adolescent knowledge during this pandemic is to provide peer education by implementing health protocols and increasing adolescent knowledge about finding information that is appropriate for the COVID-19 pandemic.

It can be seen that respondents who have good knowledge but lack understanding about Covid 19 are $15.38 \%$ of respondents. In the impact column table, it shows that respondents who know the impact of covid 19 are good but have not implemented adolescent reproductive health by $27.69 \%$. The results of data analysis using chi-square stated that the hypothesis was rejected because the p-value on the knowledge, knowledge and impact variables was $>0.05$.

\section{DISCUSSION}

A survey conducted by UNICEF 4000 teenagers related to covid-19 shows that there are still teenagers $(25 \%)$ who do not know anything about covid $19^{5}$. Some 
know the symptoms of this disease, but do not know how to prevent it. There was an increase in knowledge after being facilitated with information to adolescents. But most of them still haven't done physical distancing. Knowledge is information obtained about objects that are received through sensory receptors and processed in the central nervous system. Knowledge is influenced by educational factors, sources of information, socio-cultural, economic, environmental, experience, and age ${ }^{3}$. The subjects in this study were teenagers with an age range of 17-20. Cognitive development in adolescents is very fast, but each teenager learns and receives information in a different way. So it is important to know the most appropriate way of learning per individual to get maximum knowledge of what is required. The strategy that can be given to increase adolescent knowledge during this pandemic is to provide peer education by implementing health protocols and increasing adolescent knowledge about finding information that is appropriate for the COVID-19 pandemic.

\section{CONCLUSION}

The results of this study indicate that female students know the impact of the COVID-19 pandemic on reproductive health well. Respondents still need more information to get about reproductive health in adolescents during the covid 19 pandemic. Strategies to increase information on adolescent reproductive health during the covid 19 pandemic must be improved to deepen adolescent knowledge in understanding reproductive health.

The strategy that can be given to increase the knowledge of adolescents during this pandemic is to provide peer education by implementing health protocols and increasing adolescent knowledge about information seeking in accordance with the covid 19 pandemic. The limitation of this research is the lack of research time so that the questionnaire data collection is only carried out in the scope of the Polytechnic
'Aisyiyah Pontianak campus and does not cover all adolescents.

\section{Acknowledgement: None}

Conflict of Interest: None

\section{Source of Funding: None}

\section{REFERENCES}

1. Prastyo, Y., Faculty, J. K., \& Health, I. (2020). The effectiveness of online counseling during the covid-19 pandemic on the level of knowledge of adolescent girls about preventing vaginal discharge | Prastyo | Journal of Borneo Holistic Health. Journal of Borneo Holistic Health, 3(2). https://doi.org/10.35334/BORTICALTH.V3 I2.1653

2. BKKBN Gives Reproductive Health Education for Teenagers in the Pandemic Era: Okezone News. (n.d.). Retrieved February 25, 2021, from https:// news.okezone.com/read/2020/07/21/1/2249 944/bkkbn-beri-edukasi-kesehatan-rehasilanak-remaja-di-era-pandemi.

3. Yuliana, E. (2017). Analysis of students' knowledge about healthy and nutritious food on snacks at school.

4. BKKBN: Unwanted Pregnancy in Indonesia Average 17.5 Percent. (n.d.). Retrieved February 25, 2021, from https:/ /nasional. kompas.com/read/2020/06/30/15030631/ bkkbn-kehamilan-tak-diinginkan-diindonesia-rata-175-persen

5. Habibi. (2020). The New Normal After Covid-19. 'Are: Bulletin of Law and Justice. Ministry of Health of the Republic of Indonesia. (n.d.). Retrieved February 25, 2021 , from https://www.kemkes.go.id/folder/view/fullcontent/structure-faq.html

6. Arta, Yohana.2020. The Impact of the Covid 19 Pandemic Disrupts Women's Access to Sanitary Pads. Available in the link https://www.kompas.com/sains/read/ 2020/05/29/180300123/dampak-pandemicovid-19-anggu-access-perempuan-dapatpembalut?page $=$ all

7. BKKBN. Adolescent population profile study (10-24 years): What's wrong with teenagers. Policy Brief of the Population Research and Development CenterBKKBN; 2010. 
8. IBI. 2020. IMPACT OF COVID-19 on Global and Regional Reproductive Health Asia Pacific. Jakarta: IBI

9. Ministry of Health. 2020. Guidelines for under-five health services during the COVID-19 emergency response For health workers

10. Muadz, M. 2007. Curriculum and Training Model for the Management of Information and Counseling Centers for Adolescent Reproductive Health (PIK-KRR). BKKBN.

11. Notoatmojo, S. 2010. Health Research Methodology. Jakarta: PT. Rineka Cipta.

12. Notoatmojo, S. 2003. Health Education and Behavior. Jakarta: PT Rineka Cipta

13. Nugroho, Taufan. 2010. Textbook of Gynecology. Yogyakarta: Nuha Medika

14. Kusmiran, E. 2011. Reproductive Health of Adolescents and Women. Jakarta: Salemba Medika.
15. Kusumandari, Erika, Arkhaesi, Nahwa., Hardian. 2012. Effect of health education on the level of knowledge, attitudes and practices of mothers in the prevention of dengue hemorrhagic fever. Young Medika Media Journal.

16. Lubis, Namora L. 2013. Psychology of Women's Health and Reproductive Development. Jakarta: Kencana.

How to cite this article: Sella Ridha Agfiany, Eka Riana, Nadiah et.al. Youth knowledge about reproductive health during the COVID-19 pandemic. International Journal of Science \& Healthcare Research. 2022; 7(1): 154-158. DOI: https://doi.org/10.52403/ijshr.20220126 